ECCOMAS

\section{Proceedia}

COMPDYN 2021

$8^{\text {th }}$ ECCOMAS Thematic Conference on Computational Methods in Structural Dynamics and Earthquake Engineering M. Papadrakakis, M. Fragiadakis (eds.) Streamed from Athens, Greece, 28 - 30 June 2021

\title{
INFLUENCE OF PRIOR IN-PLANE DAMAGE ON THE OUT-OF- PLANE RESPONSE OF NON-LOAD BEARING UNREINFORCED MASONRY WALLS UNDER SEISMIC LOAD
}

\author{
Bogdan Šakić1 ${ }^{1}$ Aleksa Milijaš ${ }^{1}$, Marko Marinković ${ }^{2}$ Christoph Butenweg ${ }^{3}$, \\ Sven Klinkel ${ }^{1}$ \\ ${ }^{1}$ Lehrstuhl für Baustatik und Baudynamik, RWTH Aachen University, Mies-Van-der-Rohe- Straße 1, \\ 52074 Aachen, Germany. \\ e-mail: sakic@lbb-rwth.aachen.de,milijas@1bb.rwth-aachen.de,klinkel@lbb.rwth-aachen.de \\ ${ }^{2}$ Department of Engineering Mechanics and Theory of Structures, Faculty of Civil Engineering, Uni- \\ versity of Belgrade, Bulevar kralja Aleksandra 73, 11000 Belgrade, Serbia. \\ e-mail: mmarinkovic@grf.bg.ac.rs \\ ${ }^{3}$ CWE - Center for Wind and Earthquake Engineering, RWTH Aachen University, Mies-van-der Ro- \\ he-Straße 1, 52074 Aachen, Germany. \\ e-mail: butenweg@1bb.rwth-aachen.de
}

\begin{abstract}
Reinforced concrete frames with masonry infill walls are popular form of construction all over the world as well in seismic regions. While severe earthquakes can cause high level of damage of both reinforced concrete and masonry infills, earthquakes of lower to medium intensity sometimes can cause significant level of damage of masonry infill walls. Especially important is the level of damage of face loaded infill masonry walls (out-of-plane direction) as out-of-plane load cannot only bring high level of damage to the wall, it can also be life-threating for the people near the wall. The response in out-of-plane direction directly depends on the prior inplane damage, as previous investigation shown that it decreases resistance capacity of the infills. Behaviour of infill masonry walls with and without prior in-plane load is investigated in the experimental campaign and the results are presented in this paper. These results are later compared with analytical approaches for the out-of-plane resistance from the literature. Conclusions based on the experimental campaign on the influence of prior in-plane damage on the out-of-plane response of infill walls are compared with the conclusions from other authors who investigated the same problematic.
\end{abstract}

Keywords: Earthquake Engineering, Unreinforced masonry walls, Out-of-plane load, Inplane damage, Out-of-plane failure. 


\section{INTRODUCTION}

Reinforced concrete frames with masonry infill walls and partition walls are popular form of construction all over the world. As infill and partition walls are not included into load-bearing system of a building, they are called Non-structural elements. Nevertheless, they are not included into load-bearing system of a building, they can be loaded with huge portion of in-plane or out-of-plane forces during earthquakes. They are not designed to withstand seismic forces and they depend on their own characteristics to resist these forces [1]. As a consequence, damage of non-structural elements often represents primary source of losses in seismic events [2]. Also, damage of non-structural elements during earthquakes can cause not only unacceptable economic losses, but also some serious safety concerns if the non-structural components and their supports are not properly designed for the expected seismic force [3]. Some examples of the damage of non-load bearing masonry walls during earthquakes are presented on Figure 1.
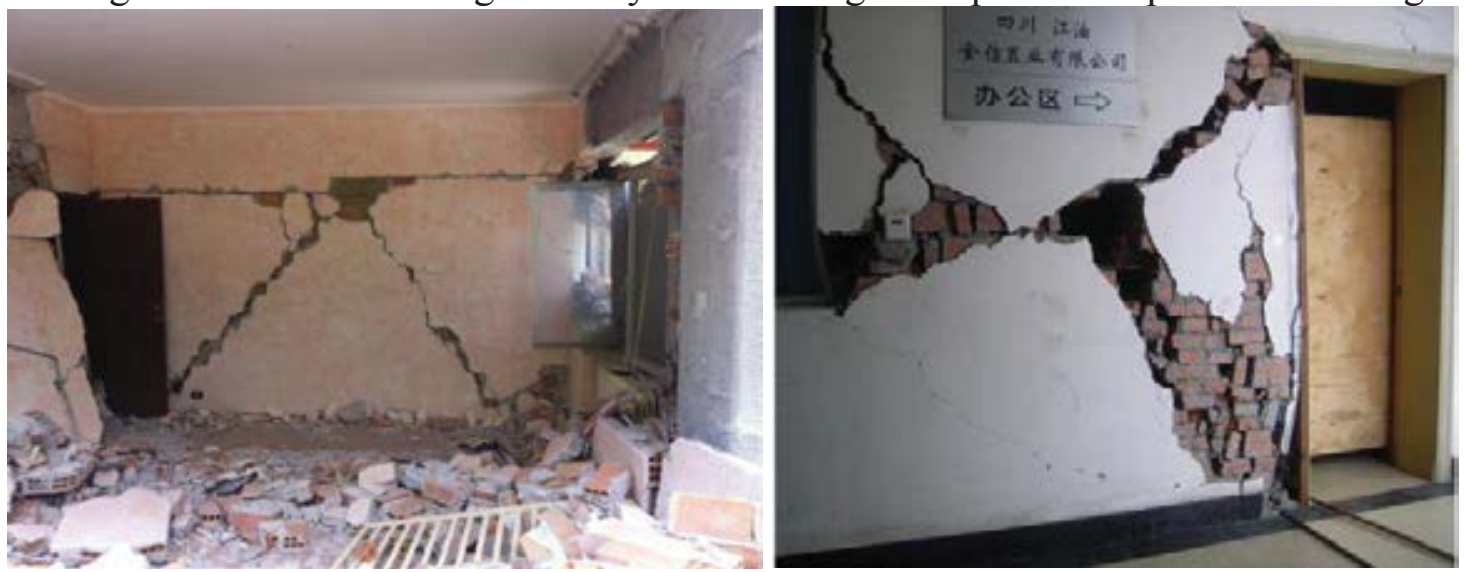

Figure 1: Left : Damage due to L'Aquila 2009 earthquake in a residential building [4,5] ; Right: Masonry wall damage of a 6-story office building in downtown area of Jiangyou City during Wenchuan earthquake in 2008 [6]

Non-structural elements can be classified either as deformation or acceleration sensitive. Deformation sensitive elements are the ones vulnerable to inter story drifts, while acceleration sensitive are the ones sensitive to the acceleration of the floors [1,7-10]. Masonry infill walls are non-structural elements which are both, deformation and acceleration sensitive elements.

Due to rigid connection of masonry infill to the surrounding concrete, as a consequence of horizontal load, compressive force is activated in the masonry wall. The paths of compressive forces in the wall mainly follow diagonal path [11-14]. Above mentioned in-plane forces can cause different failure modes of masonry infill walls, such as infill sliding shear failure, diagonal cracking failure, diagonal compression failure and corner crushing failure [12,14].

Masonry infill walls are also acceleration sensitive elements. Face load or out-of-plane loading on the masonry walls is proportional to the acceleration and the mass of the wall. Before affecting walls loaded in out-of-plane direction, ground motion is modified and filtered by two actions: by the response of in-plane loaded walls and by the response of floor diaphragm $[15,16]$. Furthermore, out-of-plane behaviour of masonry infill walls is highly influenced by arching effect, which introduces membrane forces into the masonry wall and increases its outof-plane strength [17-19]. However, arching effect, as well as out-of-plane behaviour of masonry walls, is highly dependent on boundary conditions [20]. In the case of good beam-towall or floor-to-wall connections, and if beams / diaphragms are rigid relative to the wall, one - way bending (arching effect) can occur. This will significantly increase walls out-of-plane strength. In the case of stiff frames, properly connected on all four sides to masonry walls, those frames can guarantee two-way bending (arching effect) and in that case, walls with low tensile 
strength can withstand high out-of-plane forces without losing its stability [17,20]. However, if in-plane forces are also imposed, connections of the infill wall to the surrounding frame can be damaged, and thus, it can decrease out-of-plane capacity. Out-of-plane deformation mechanism for two-sided and four-sided walls are presented on Figure 2.
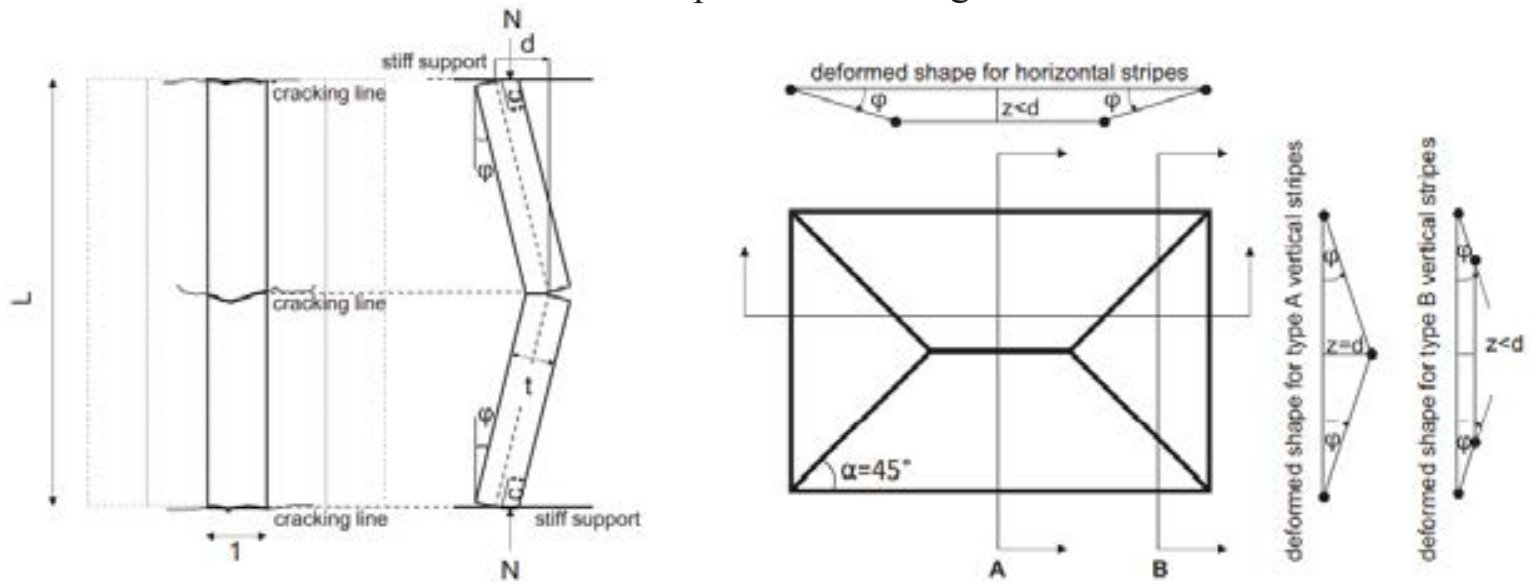

Figure 2: Crack pattern of two - sided (left) and four - sided (right) masonry infill walls subjected to outof-plane loading $[19,21]$

Even though highest accelerations in buildings occur at highest floors, out-of-plane failure of masonry infills often occurs at intermediate floors. The reason for this is the interaction of in-plane and out-of-plane forces during earthquakes. Effect of in-plane and out-of-plane interaction is nicely presented in the paper of Ricci et al. [22], and it is shown on Figure 3. There it can be seen, that as a consequence of in-plane damage on masonry infills at intermediate building stories, out-of-plane capacity is reduced and can be smaller than out-of-plane strength demand.
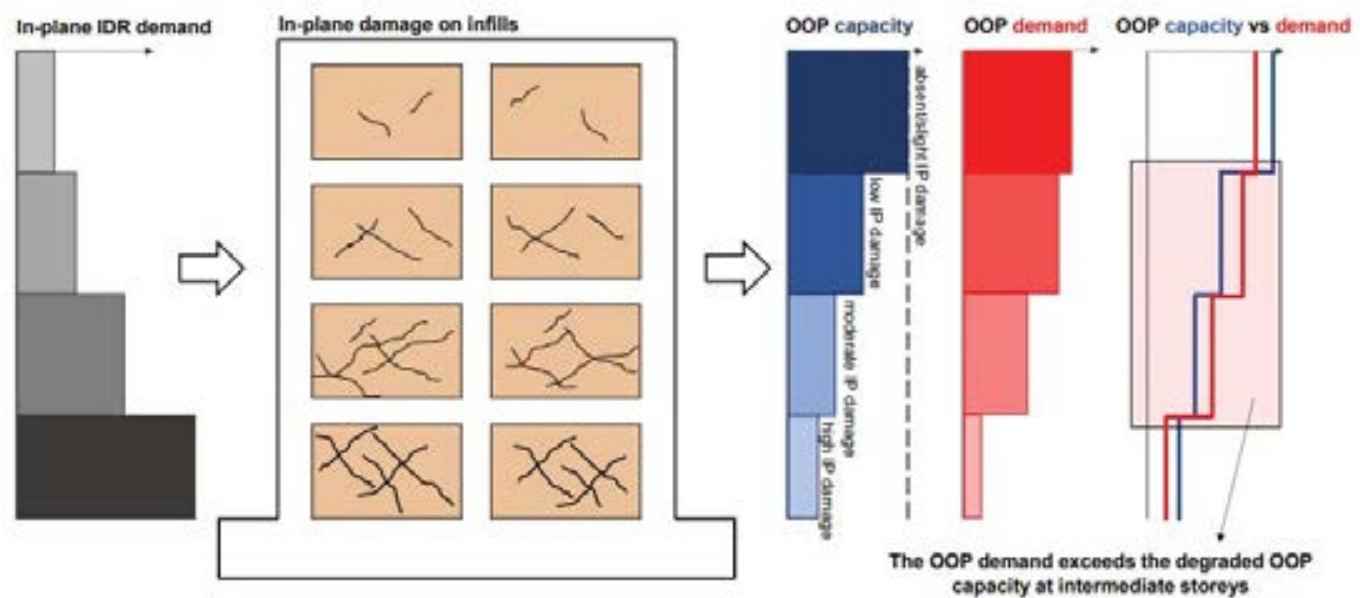

Figure 3: Influence of in-plane and out-of-plane interaction on the out-of-plane capacity at different floor levels[22]

Influence of prior in-plane damage on the out-of-plane load-capacity of masonry walls has been highlighted in few experimental campaigns. Angel and Abrams [23] stated that the slenderness $(\mathrm{h} / \mathrm{t})$ of infill wall has the highest effect on the decrease of out-of-plane capacity after prior in-plane damage. Flanagan and Bennett [24] investigated the behaviour of prior in-plane damage on the out-of-plane capacity of masonry walls made of clay bricks connected to steel frames. They stated that prior in-plane damage had minor effect on the out-of-plane capacity of the walls, but that it has induced higher out-of-plane displacements and reduction of out-ofplane stiffness. 
In the experimental campaign conducted by Calvi and Bolognini [25] walls previously exposed to $0.4 \%$ of in-plane drift had decrease of out-of-plane capacity for around 50 percent and for prior in-plane drift of $1.2 \%$, out-of-plane capacity decreased for the factor of 5.62. Investigating different thicknesses and in-plane drift level influence on out-of-plane capacity, Da Porto et al. [26] pointed out that in-plane drift limit of 0,5\% percent given by Italian Building Code is appropriate for thick walls, but not for the thin masonry walls. Hak et al. [27] pointed out that the specimens with prior in-plane drift of 1.0 and $1.5 \%$ for fully infilled walls had similar out-of-plane residual capacity, but that the significant stiffness degradation of approximately $40 \%$ occurred. Specimen subjected to prior in-plane drift of 2,5\% had decrease of outof-plane capacity around $60 \%$, followed with stiffness degradation of $75 \%$. Furtado et al. [28] came to the conclusion that the walls without prior in-plane damage had 4 times higher out-ofplane capacity compared to the specimen with prior in-plane drift of $0,5 \%$. It was also pointed out that prior in-plane damage significantly decreased out-of-plane wall stiffness. DiDomenico [19] and Ricci et al. [29,30] stated after their experimental campaign on two different slenderness ratios of masonry infills, 15.2 and 22.9, that slenderness ratio affects in-plane and out-ofplane interaction if it is lower than 20.4 and that higher values of slenderness ratio have similar influence on the interaction as the slenderness ratio of 20.4. They pointed out the importance of "critical" in-plane drift, after which, further increase of in-plane displacement will decrease out-of-plane capacity of the wall. Akhoundi et al. [31] concluded that prior in-plane damage reduces out-of-plane stiffness and strength. They also stated the importance of the workmanship, as bad constructed top joints can significantly decrease out-of-plane strength of the wall. In their experimental campaign, Butenweg and Marinković [32] pointed out that prior in-plane drift of $1.25 \%$ led to the 8-10 times smaller out-of-plane capacity compared with the wall without prior damage. De Risi et al. [33] investigated different length-to-height (w/h) ratios of masonry infills with the same slenderness ratios of 22.9. They stated that specimens with higher $\mathrm{w} / \mathrm{h}$ ratios (1.26) showed higher level of damage after cycles of in-plane loading and higher reduction of out-of-plane strength compared to the square walls. Xie et al. [34] investigated 7 full-scaled masonry infilled one-span reinforced concrete frames for a typical classroom building in China. The investigation showed that prior in-plane drift significantly decreases out-ofplane wall capacity, when certain value of prior in-plane drift is reached. According to the authors, this limit value is between $0.1-0.3 \%$ of in-plane drift. Da Porto et al. [35] conducted experimental campaign on thick masonry infill walls with and without openings and stated that after different levels of in-plane drifts, out-of-plane capacity of thick infills walls is satisfactory. In the experimental campaign of Di Domenico et al. [36] it was concluded that square panels are less prone to the interaction of in-plane and out-of-plane compared to the rectangular ones.

\section{EXPERIMENTAL CAMPAIGN AND TEST SETUP}

In order to investigate the influence of prior in-plane damage on out-of-plane behaviour of unreinforced masonry infill walls, experimental campaign was conducted on 2 wall specimens. This experimental campaign was carried out in the scope of the project "Development of an innovative approach for decoupling infills and non load-bearing masonry walls from the main structure" [37]. Walls were made of clay bricks, and the dimension of the bricks were $247 \mathrm{x}$ $249 \times 300 \mathrm{~mm}^{3}$. Dimensions of wall specimens and surrounding concrete frame are shown on Figure 4. 

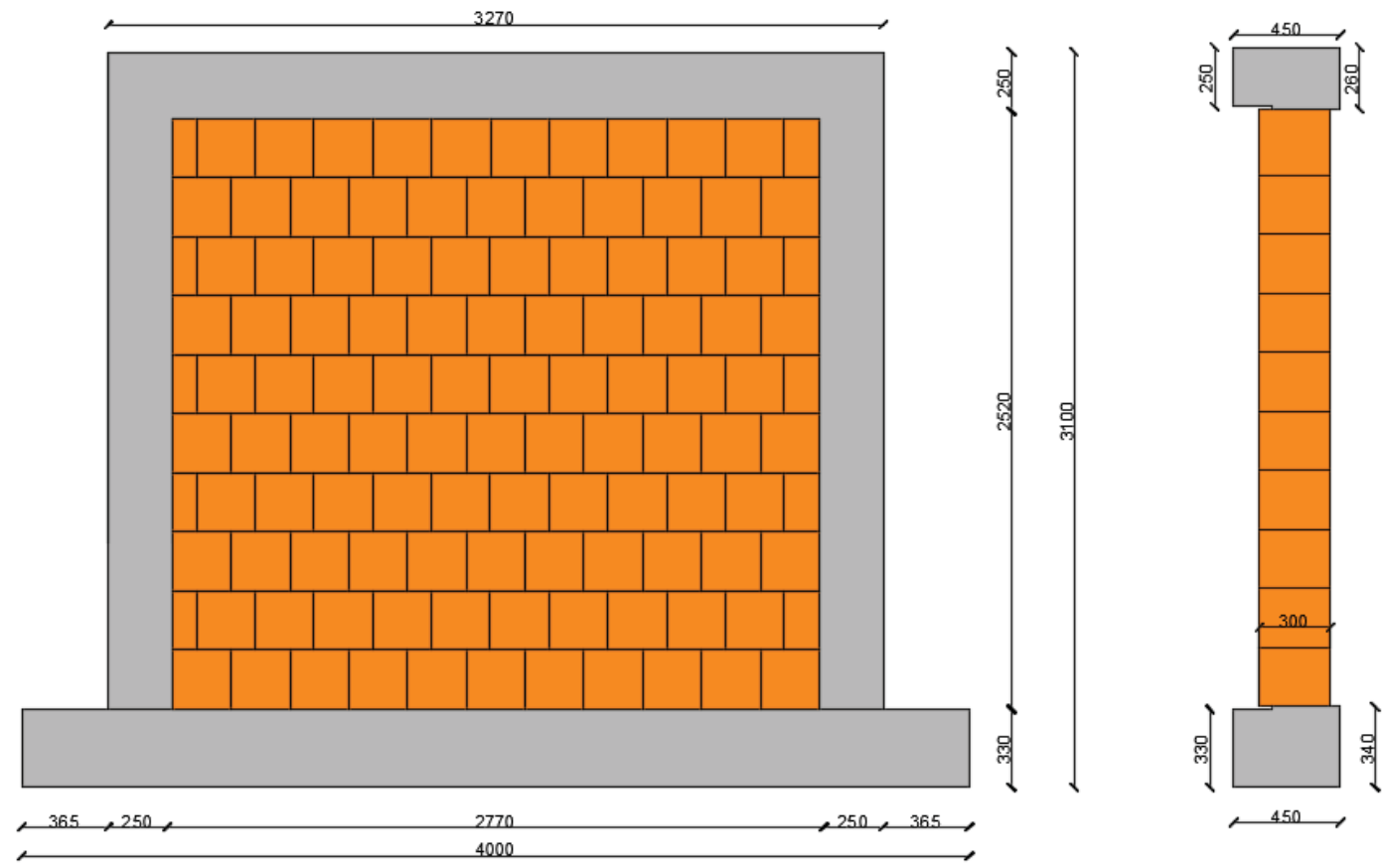

Figure 4: Front and side view of frame and wall specimens for tests T1 and T2

Characteristic values of used materials are presented in Table 1. Only bed joints were mortared, using thin layer mortar Maxit D900.

Table 1: Material property values for the materials used in experimental campaign

\begin{tabular}{|c|c|c|c|c|c|}
\hline \multicolumn{6}{|c|}{ Tests $\mathrm{T} 1$ and $\mathrm{T} 2$} \\
\hline \multirow{3}{*}{$\begin{array}{l}\text { Mortar } \\
\text { MAXIT }\end{array}$} & Mortar type & \multicolumn{2}{|c|}{$\begin{array}{c}\text { Compressive strength } \\
\mathrm{fm}_{\mathrm{m}}\left(\mathrm{N} / \mathrm{mm}^{2}\right)\end{array}$} & \multicolumn{2}{|c|}{$\begin{array}{l}\text { Flexural tensile strength } \\
f_{\mathrm{m}, \text { flex }}\left(\mathrm{N} / \mathrm{mm}^{2}\right)\end{array}$} \\
\hline & Thin layer mortar & \multicolumn{2}{|c|}{12.8} & \multicolumn{2}{|c|}{2.4} \\
\hline & $\begin{array}{c}\text { General purpose } \\
\text { mortar }\end{array}$ & \multicolumn{2}{|c|}{16} & \multicolumn{2}{|r|}{2.4} \\
\hline \multirow{3}{*}{$\begin{array}{l}\text { Brick } \\
\text { Thermo } \\
\text { plan } \\
\text { SX10 }\end{array}$} & $\begin{array}{c}\text { Dimensions L/T/H } \\
(\mathrm{mm})\end{array}$ & $\begin{array}{r}\text { Compr } \\
\mathrm{f}_{\mathrm{ck}}\end{array}$ & $\begin{array}{l}\text { sive strength } \\
\mathrm{N} / \mathrm{mm}^{2} \text { ) }\end{array}$ & Voids (\%) & $\begin{array}{l}\text { Gross dry den- } \\
\text { sity }\left(\mathrm{kg} / \mathrm{m}^{3}\right)\end{array}$ \\
\hline & $247 / 300 / 249$ & $\begin{array}{c}\text { Verti- } \\
\text { cal }\end{array}$ & $\begin{array}{l}\text { Longitudi- } \\
\text { nal }\end{array}$ & \multirow{2}{*}{56} & \multirow{2}{*}{600} \\
\hline & & 9.57 & 1.67 & & \\
\hline \multirow{2}{*}{ Masonry } & \multicolumn{2}{|c|}{$\begin{array}{c}\text { Compressive strength } \\
\mathrm{f}_{\mathrm{k}}\left(\mathrm{N} / \mathrm{mm}^{2}\right)\end{array}$} & \multicolumn{3}{|c|}{$\begin{array}{l}\text { Modulus of elasticity } \\
\qquad E_{\mathrm{m}}\left(\mathrm{N} / \mathrm{mm}^{2}\right)\end{array}$} \\
\hline & \multicolumn{2}{|l|}{2.68} & \multicolumn{3}{|c|}{2680} \\
\hline
\end{tabular}

Masonry infill walls were connected on all 4 sides to the surrounding concrete frame. Axial force of $200 \mathrm{kN}$ per column was introduced by hydraulic actuator, and it was kept constant during both experiments. In-plane displacement was imposed by steel frame and hydraulic 
actuators. Steel bars and plates were placed to keep self-equilibrium and to keep the force in the system. Out-of-plane loading was imposed using 4 airbags. Velocity of the applied load for the out-of-plane direction was $50 \mathrm{~N} / \mathrm{sec}$. Reaction plate was made at the back side of the wall, to keep airbags in the contact with the wall. Test setup is presented on Figure 5.

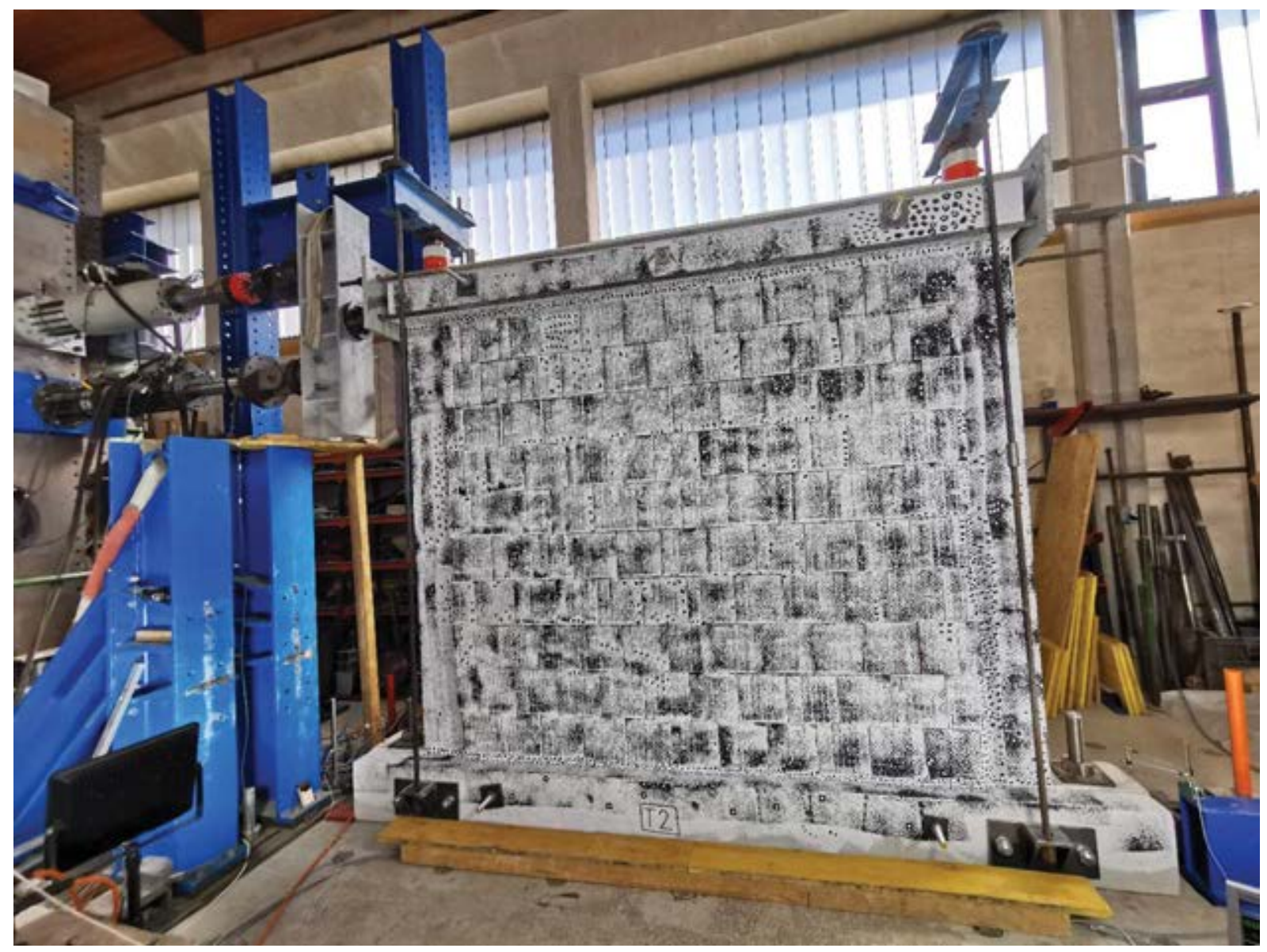

Figure 5: Test specimen with test setup for in-plane movement of the specimen

\subsection{Test T1}

Test T1 was pure out-of-plane test, without any prior in-plane drift imposed. Velocity of the load applied in out-of-plane direction was $50 \mathrm{~N} / \mathrm{sec}$, and it was introduced by 4 airbags, in load cycles of $90 \mathrm{kN}$. At the end of the first cycle, highest displacement of $1.6 \mathrm{~mm}$ was measured at the center of the wall, as it is shown on Figure 6. Wall didn't exhibit any kind of visible damage at that moment. As it can be seen from the Figure 6, based on out-of-plane displacements, twoway arching was activated. 


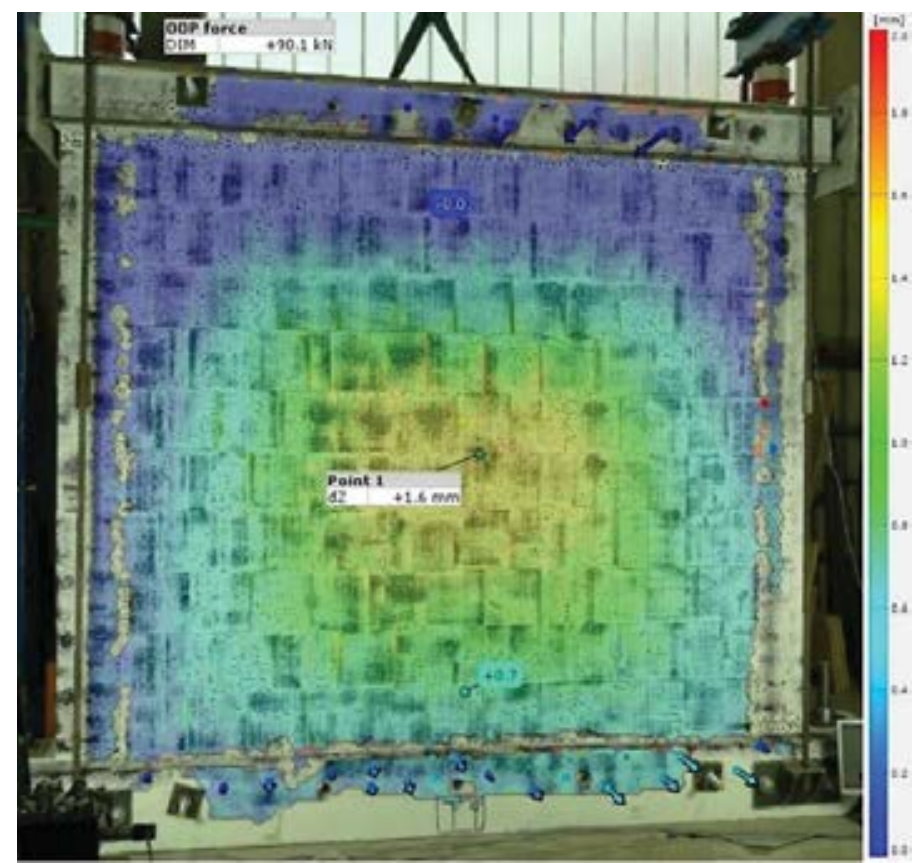

Figure 6: Out-of-plane displacement of infill wall at the end of first cycle of test T1

At the end of the first cycle, residual displacement in out-of-plane direction was minimal and it was near 0. During the second cycle, when the force of around $136 \mathrm{kN}$ was reached, first small cracks in the mortar joints occurred. Future increase of the load led to the first cracks in the bricks in the upper right part of the wall, which occurred at $154 \mathrm{kN}$. When force reached $170 \mathrm{kN}$, high intensity crack of the bricks occurred, which was followed by fast increase of outof-plane displacement with small increase of out-of-plane force. At the force of $176 \mathrm{kN}$, brittle failure of the wall occurred. It was governed by failure of bricks in the upper right part of the wall. Rotation of the wall due to arching effect occurred through the cracked cross section of the brick, which led to brittle and fast failure of the wall in out-of-plane direction. At the moment of failure, displacement at the center of the wall was $9.86 \mathrm{~mm}$. Complete force - displacement curve of the test T1 is shown on Figure 7. Outlook of the test specimen after the brittle collapse can be seen on Figure 7.
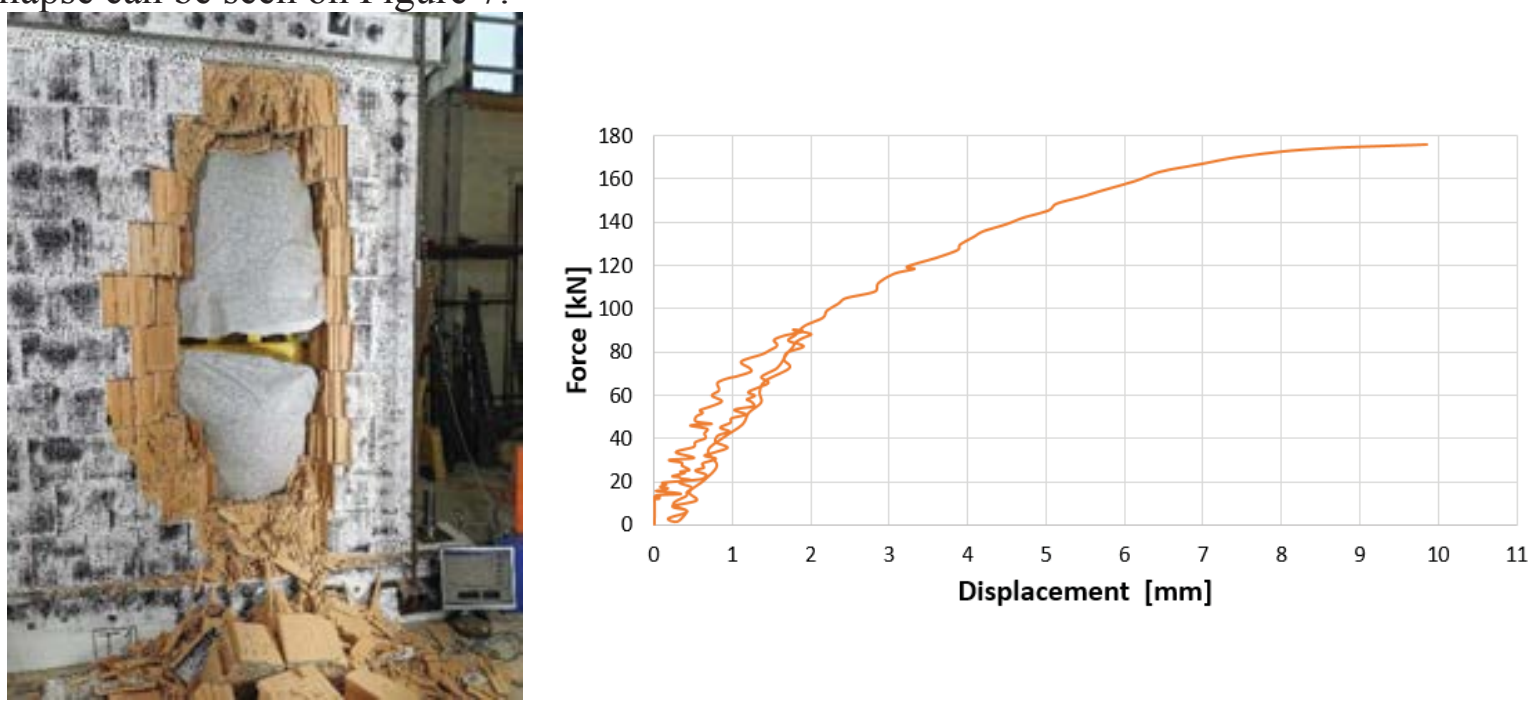

Figure 7: Look of test specimen $\mathrm{T} 1$ at the end of the test (left) and force - displacement curve for the out-ofplane behaviour of test specimen T1 (right) 
Top rotation point for the arching effect was moved from the connection of the top beam and infill wall, to the cracked section of the bricks in the last row. This is shown on Figure 8, where it can be seen that cracks initiate through the thickness of the wall, breaking thin webs of the brick and making this weakened cross section as a plane around which the wall rotates. This type of the behaviour can be explained with yield line theory, presented for the out-ofplane behaviour of masonry infills by Dawe and Seah [21]. In their approach, mortar joints at the wall middle and at the top and bottom connection of masonry infill to surrounding concrete represent cracked cross sections. When the test specimen T1 was bricked up, mortar connection of the wall and top beam was made of high quality thin bed layer mortar, which was inserted using the pump under high pressure. Nevertheless, it is important to point out that this high quality of mortar joint connections to the surrounding concrete is difficult to have on a construction site, and it is not expected to be done in that manner, as it is time-consuming.

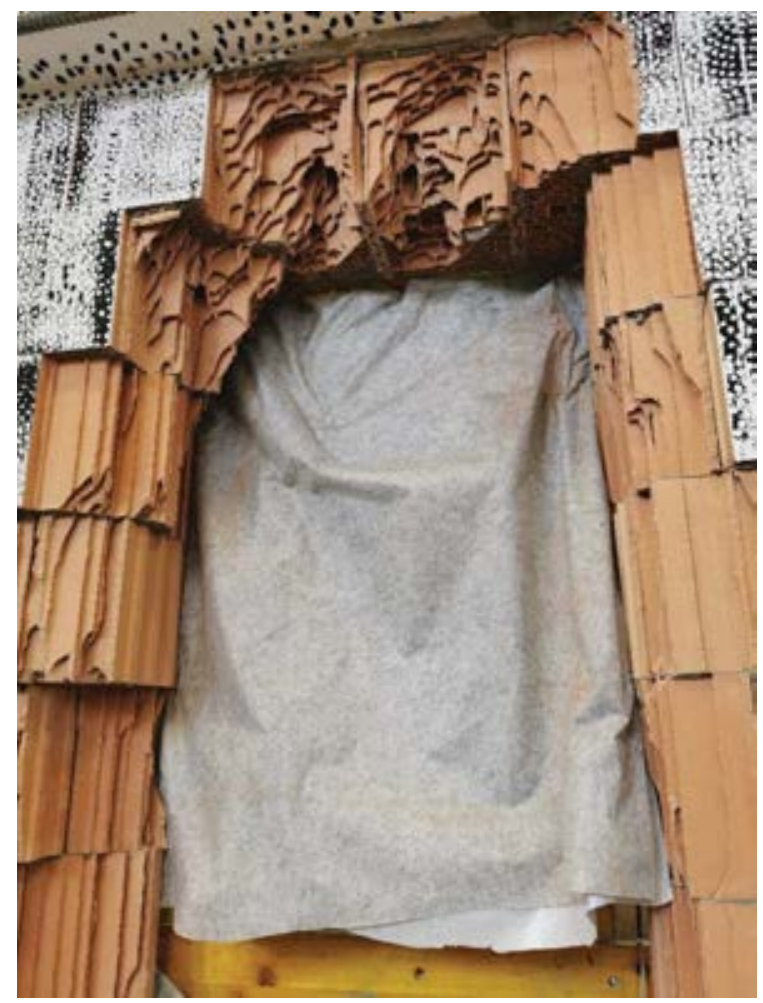

Figure 8: Look of test specimen T1 at the end of the test and cracks penetrating through the thickness of the wall in the plane of the rotation, cause collapse of thin brick webs

\subsection{Test $\mathrm{T} 2$}

Test specimen T2 was subjected to $1.2 \%$ of in-plane drift prior to the out-of-plane loading. Complete hysteresis curves of force-displacement and force-drift for both directions of inplane load are shown on Figure 9. 

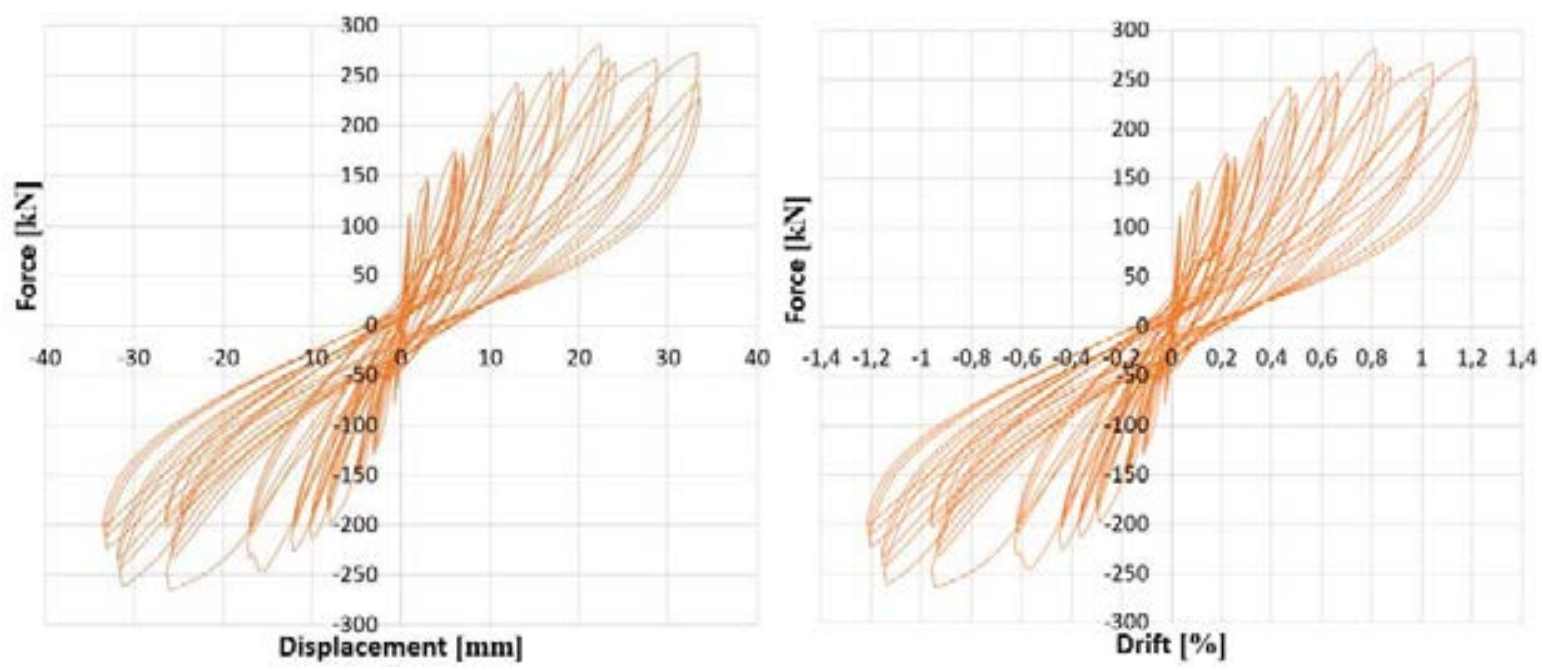

Figure 9: Force - displacement (left) and force - drift (right) hysteretic curve for the in - plane phase of loading of test specimen $\mathrm{T} 2$

For each cycle of in - plane drift, three amplitudes were reached. Time period for reaching prescribed displacement for each of the amplitudes was 15 seconds. First change of the stiffness was noticed in the fourth cycle, when in-plane drift of $0.022 \%$ was reached. Reason for the first dropdown of the stiffness were initiations of the cracks in mortar bed joints, mainly at right part of the wall. Force that was reached at that moment was $60 \mathrm{kN}$. Surface plot of the strains is shown on Figure 10a.

Highly pronounced compressive struts, characteristic for the masonry infill walls, occurred in sixth cycle, with prescribed drift of $0.11 \%$. At this point, bricks were still undamaged. Only visible damages were a bit cracked mortar joints at the connection of the infill wall to the concrete columns and top beam. Surface plots of the strains are shown on Figures 10b and 10c.

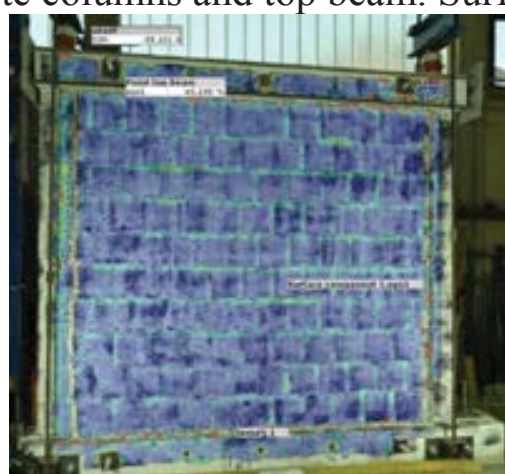

a)

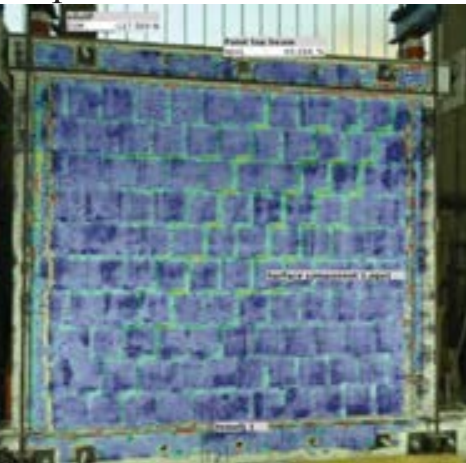

b)

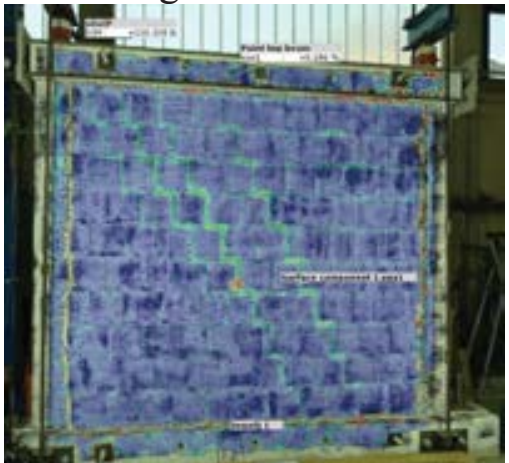

c)

Figure 10: Surface plot of the wall strains of specimen T2 at drift levels of $0.012 \%$ (a); $0.11 \%$ when moving the wall from right to left (b); and $0.11 \%$ when moving the wall from left to right (c)

Peak force of the in-plane hysteresis curve for both directions of in-plane loading was reached at $11^{\text {th }}$ cycle. Corresponding force of $280 \mathrm{kN}$ was reached when the frame was pushed from left to the right. Drift reached at this cycle was $0.8 \%$. Surface plot of the tensile strains at drift level of $0.8 \%$, while moving the wall from left to right, is presented on Figure 11a. At the end of $15^{\text {th }}$ cycle, last for in-plane phase of the test, drifts of $1.2 \%$ were reached, and the forces were 225 and $196 \mathrm{kN}$, respectively. Surface plot of the tensile strains at drift level of $1.2 \%$, while moving the wall from left to right and right to left, are presented on Figures $11 \mathrm{~b}$ and $11 \mathrm{c}$. 


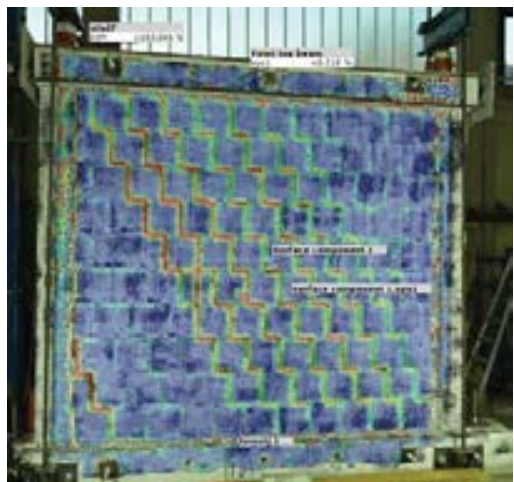

a)

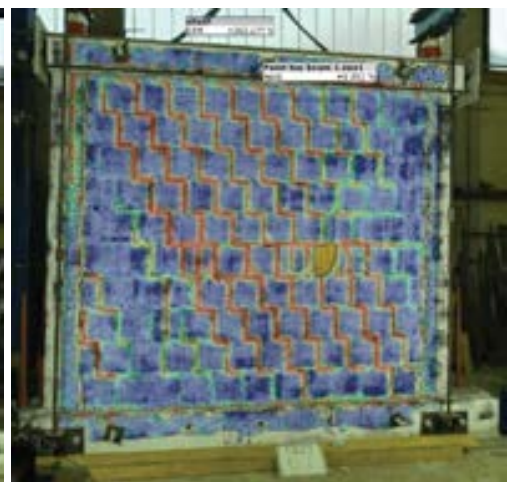

b)

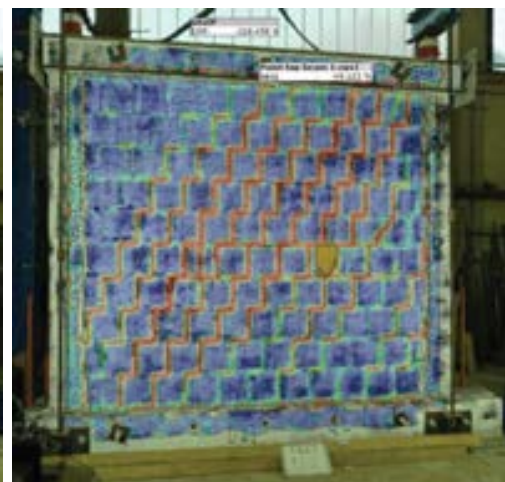

c)

Figure 11: Surface plot of the wall strains of specimen T2 at drift levels of $0.8 \%$ (a) ; $1.2 \%$ when moving the wall from left to right (b); and $1.2 \%$ when moving the wall from right to left (c)

At this level of in-plane drift, significant amount of the damage on infill wall was noticed. At the back side of the wall, almost along whole length of the wall, outer brick shells were cracked in rows 5 and 6 . Cracks were also pronounced on the bricks at top right and left corner, and they also went through concrete columns. On the front side of the wall, outer shells of the bricks felt off from 2 bricks in the $5^{\text {th }}$ row. Minor diagonal cracks were seen on the bricks close to the columns on the front side off the wall, which were following the trajectory of compressive struts.

In the second phase of the test, investigation of the out-of-plane capacity of the wall with prior in-plane damage was conducted. Out-of-plane loading was carried out in 11 cycles. In the last cycle, while reaching out-of-plane force of $87 \mathrm{kN}$, high increase of out-of-plane displacement occurred, followed by dropdown of out-of-plane force. In order to prevent brittle failure, test was stopped. Out-of-plane displacement at the end of the test was $18.42 \mathrm{~mm}$, as it is shown on Figure 12. Furthermore, from the Figure 12, where the surface plot of out-of-plane displacement is shown, it can be seen that two-way arching was exhibited, as in test T1. It can be concluded that even though mortar joint at the connection of infill wall and top beam had cracks, they were insufficient to jeopardize two-way arching. Out-of-plane displacement of the wall from the laboratory is shown on Figure 13, as well as force-displacement curve for the second phase of test $\mathrm{T} 2$.

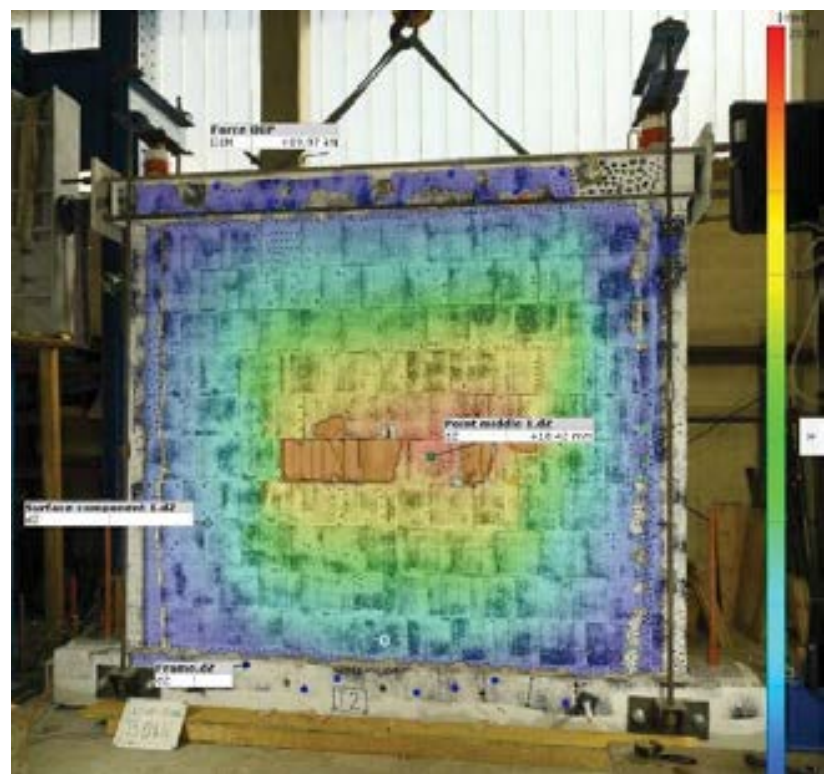

Figure 12: Surface plot of out-of-plane displacement at the end of the test on test specimen T2 

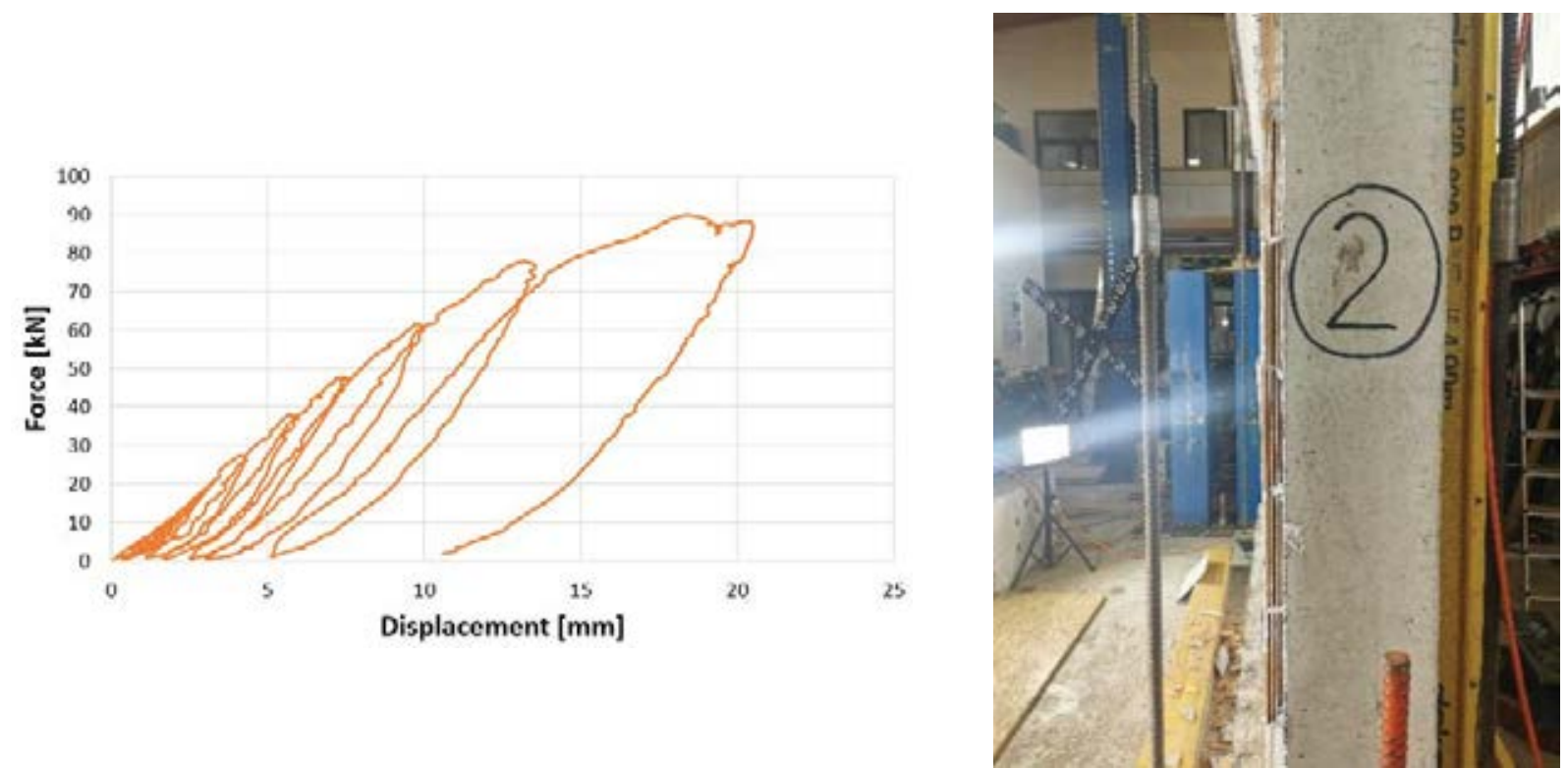

Figure 13: Force - displacement curve of the out-of-plane loading phase of test specimen T2 (left) and lateral look of the out-of-plane displacement at the end of the test (right)

\section{COMPARISON OF THE OUT-OF-PLANE BEHAVIOUR OF TEST SPECIMENS T1 AND T2}

As it can be seen from Figures 6 and 12, and surface plots of out-of-plane displacements of the walls $\mathrm{T} 1$ and $\mathrm{T} 2$, both walls remained in full contact on all 4 sides to the surrounding concrete. This implicates that the walls exhibited two-way bending and arching effect. Such fact goes on contrary with the conclusions of some of the authors stated in the literature review, as it is often the case that due to prior in-plane drift, connection of the masonry infill and concrete frame is partially or completely lost. Full connection of the masonry infill and concrete frame on all 4 sides during all the phases of in-plane and out-of-plane loading in tests T1 and T2 is a consequence of unrealistically high bond strength of the mortar joints. The reason for that high bond strength of connection joints was, as it was already explained in Chapter 2, the use of high-pressure pump for placing the mortar. This construction procedure highly increased bond strength of mortar joints. Use of the pump in that manner is inapplicable in practice due to timeconsuming reasons and construction difficulties on the construction site, so it can be said that this full connection of infill walls to surrounding concrete after in-plane loading cannot truly represent real behaviour in practice.

Comparison of the out-of-plane force-displacement curves for tests T1 and T2 is shown on Figure 14. It can be seen that reduction of the out-of-plane capacity was $51 \%$. 


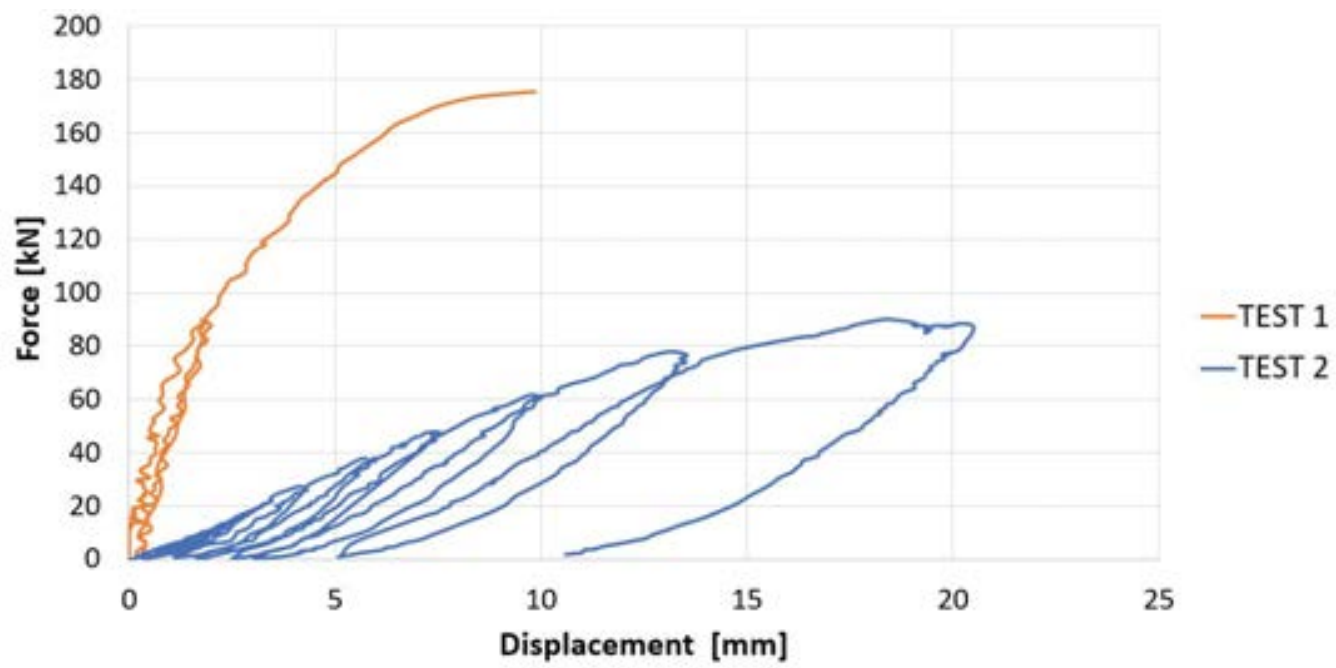

Figure 14: Force - displacement curves of the out-of-plane loading phase for test specimens T1 and T2

Also, it can be seen that prior in-plane damage triggered significant decrease of stiffness in out-of-plane direction. This goes in the line with the conclusions of all previous experimental campaigns from the literature, where the authors pointed out the importance of prior in-plane damage on the stiffness degradation in out-of-plane direction.

It is important to mention brittle behaviour of test specimen T1. Even though this specimen showed high level of out-of-plane capacity compared to the test specimen T2, wall T1 had small out-of-plane displacements at the failure, compared to the ones reached in test T2. Comparing the values of displacement at failure and wall thickness, out-of-plane displacement at failure of wall $\mathrm{T} 1$ was equal to $3.29 \%$ of the wall thickness. This represents quite a small value for pure out-of-plane tests, as according to some theoretical approaches for out-of-plane capacity, displacement at the failure can reach around $50 \%$ of wall thickness [18]. The reason for small outof-plane displacement at failure for test specimen $\mathrm{T} 1$ can also be explained with perfect boundary conditions and connection of the infill wall with surrounding frame. This fact decreased the possibility for the rotation of the wall through the cross sections in the mortar plane. On contrary, rotation cross sections and "hinges" occurred at the first and last row of the bricks, at the moment when the bricks started to crack through the thickness of the wall. Also, this was the reason for the fast and brittle failure after appearance of the cracks. As it is already mentioned, test specimen T2, subjected to prior in-plane loading, kept the connection to the surrounding concrete for the entire duration of the test. Nevertheless, the main reason for the increase of the displacement at failure in out-of-plane direction during the second phase of test 2 was the influence of prior in-plane loading on mortar joints within the wall and next to the surrounding concrete. This prior in-plane loading decreased the level of rigidity of mortar connections and also it changed the boundary conditions at the connection of top beam and the wall. For the test $\mathrm{T} 1$, this connection was almost clamped and for test $\mathrm{T} 2$ it showed more hinged-like connection due to prior in-plane loading.

\section{COMPARISON OF TEST RESULTS WITH ANALYTICAL APPROACHES}

Results from the test specimens described in experimental campaign were compared with the existing analytical approaches which take into account influence of prior in - plane damage on out-of-plane capacity of masonry infill walls. The interaction of in-plane and out-of-plane loading is usually taken into account with factor $\mathrm{R}$, which represents the decrease of out-ofplane capacity due to prior in-plane damage. Factor $\mathrm{R}$ is related to the level of in-plane drift to 
which the wall had been previously exposed, so it is a kind of displacement - based and not strength - based factor. First one to propose reduction factor which takes into account prior inplane damage to the out-of-plane capacity was Angel [23], and the reduction factor is shown in Equation 1. Reduction factor can be used if in-plane drift is higher than "critical" in-plane drift at which first brick cracking occurs. Else, $\mathrm{R}=1$. Interstory drift ratio is denoted as IDR.

$$
R=\left(1,08-0,015\left(\frac{h}{t}\right)-0.00049\left(\frac{h}{t}\right)^{2}+0.000013\left(\frac{h}{t}\right)^{3}\right)^{\frac{I D R}{2 I D R_{c r}}}
$$

New Zealand standard NZSEE 2017 [38] proposes reduction factor which takes into account slenderness ratio of the wall. This reduction factor is shown in Equation 2.

$$
R=\min \left(1.1\left(1-\frac{h / t}{55}\right) ; 1\right)
$$

FEMA 274 [39], FEMA 356 [40], ASCE/SEI 41-06 [41] and ASCE 41-13 [42] proposed reduction factor $\mathrm{R}$ equal to 0.76 for all situations of the interaction of prior in-plane damage on out-of-plane capacity.

FEMA 306 [43] suggests to use Equation 1 for the calculation of reduction factor, with further description that for moderate in-plane damage it should be taken into account that $\mathrm{IDR}=\mathrm{IDR} c r$ and that for severe damage IDR=2IDRcr.

ASCE/SEI 41-17 [44] suggest that reduction factor R should be equal to 0.6. It is calculated using Equation 1, for the situation when IDR=2IDRcr and slenderness ratios is equal to 25.

Morandi et al. [45]proposed reduction factor to be calculated using Equation 3. Their reduction factor is fitted and calibrated for slender infills.

$$
\begin{array}{cc}
1-2.67 I D R & I D R \leq 0.30 \% \\
0.2 & 0.30 \%<I D R \leq 1.00 \% \\
0 & I D R>1.00 \%
\end{array}
$$

Based on the experimental results, Verlato et al. [46] proposed Equation 4 for the reduction factor.

$$
\begin{array}{cc}
1-0.86 I D R & I D R \leq 0.70 \% \\
0.4 & 0.70 \%<I D R \leq 1.20 \% \\
0 & I D R>1.20 \%
\end{array}
$$

Cavaleri et al. [47] reduction factor R reported in Equation 5, has been proposed based on the experimental database.

$$
R=\min \left(0.26 I D R^{-0.37} ; 1\right)
$$

Ricci et al. [29] proposed reduction coefficient $\mathrm{R}$ using statistical regression, based on the some results from the literature. This reduction coefficient is shown in Equation 6. 


$$
R=\min \left(0.14 I D R^{-1.12} ; 1\right)
$$

Later, Ricci et al. [30] also proposed another reduction coefficient R, after conducting experimental campaign. This reduction coefficient is based on statistical regression and it is shown in Equation 7, and it is calibrated according to Authors for thin walls $(\mathrm{h} / \mathrm{t}>15.2)$. For walls with lower slenderness ratio, Equation 8 is proposed. Equation 8 is calibrated based on two wall specimens from the literature with slenderness ratio equal to 8.8 .

$$
\begin{aligned}
& R=\min \left\{1 ;\left(0.98-0.04 *\left(\min \left(\frac{h}{t} ; 20.4\right)\right) * I D R^{-0.97}\right)\right\} \\
& R=\min \left\{1 ;\left(1.21-0.05 *\left(\min \left(\frac{h}{t} ; 20.4\right)\right) * I D R^{-0.89}\right)\right\}
\end{aligned}
$$

Based on their experimental campaign, Akhoundi et al. [31] proposed that reduction of outof-plane capacity due to prior in-plane damage should be taken into account using Equation 8.

$$
R=\frac{2-I D R}{2}
$$

Da Porto et al. [35] used data from their experimental campaign on thick infill walls to proposed reduction coefficient R, shown in Equation 9.

$$
R=\frac{1}{2.1} *\left(1.1 * e^{-(2.6 * I D R)^{2}}+1\right)
$$

Using statistical regression and data available from the literature, Di Domenico at el [36] proposed reduction factor $\mathrm{R}$ for thin and thick walls, presented in Equations 10 and 11, respectively. Equation 10 can be used if $h / t>15$, while Equation 11 can be used for walls with $h / t>$ 8.

$$
\begin{aligned}
& R=\min \left\{1 ;\left(1.438-0.245\left(\frac{w}{h}\right)-0.042 *\left(\min \left(\frac{h}{t} ; 20.4\right)\right) * I D R^{-0.719}\right)\right\} \\
& R=\min \left\{1 ;\left(1.510-0.190\left(\frac{w}{h}\right)-0.050 *\left(\min \left(\frac{h}{t} ; 20.4\right)\right) * I D R^{-0.730}\right)\right\}
\end{aligned}
$$

In order to use some of the above mentioned Equations for the calculation of reduction coefficient $\mathrm{R}$, input data should be IDRcr which represents in-plane drift at which first crack in the wall occurs. For test T2, described in this paper, drift of $0.027 \%$ is taken as IDRcr. At that drift level, first stepwise cracks through the wall occurs, as it is shown on Figure 15. 


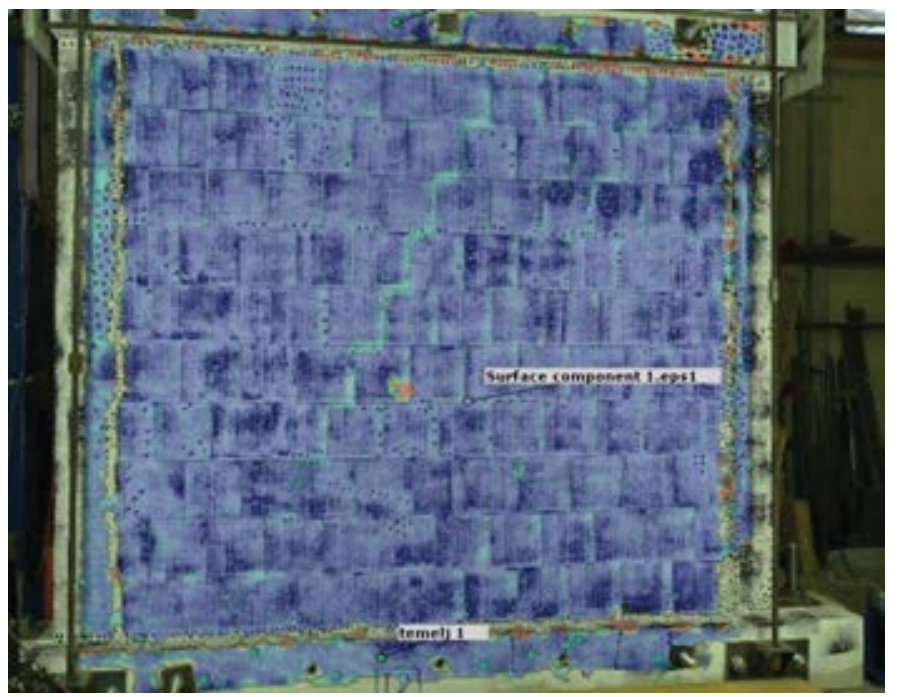

Figure 15: Surface plot of crack pattern of the specimen T2 under in - plane drift of $0.027 \%$

Above mentioned analytical approaches for the calculation of out-of-plane capacity due to prior in-plane damaged are compared with measured values for test specimen T2. Values of the parameters necessary for the use of Equations 1-12 are the following: $\mathrm{h} / \mathrm{t}=8.4 ; \mathrm{w} / \mathrm{h}=1.1 ; \mathrm{IDR}=$ $1.2 \%$ and IDRcr $=0.027 \%$. In experimental campaign, with above mentioned values, test specimen T2 exhibited reduction of the out-of-plane capacity due to prior in-plane damage for a factor $\mathrm{R}=0.49$. Comparison of the experimental result with existing analytical approaches is shown on Figure 16. Values of the predicted reduction coefficients are shown in Table 2.

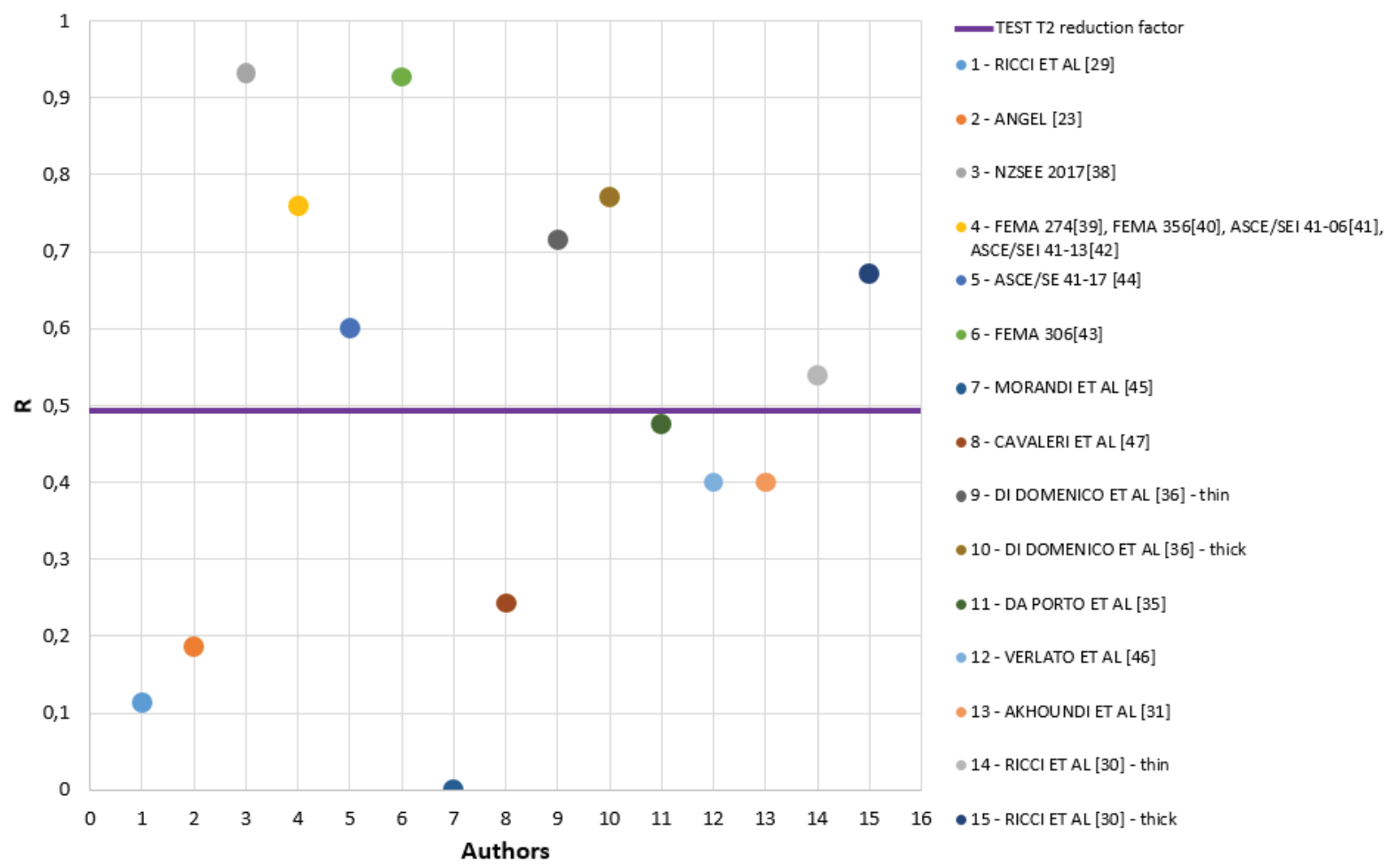

Figure 16: Comparison of predicted and measured reduction factor for test specimen T2 using existing analytical approaches 
Bogdan Šakić, Aleksa Milijaš, Marko Marinković, Christoph Butenweg, Sven Klinkel

Table 2: Comparison between predicted and experimental reduction factor for different analytical approaches

\begin{tabular}{|c|c|c|}
\hline Author & $\mathrm{R}_{\text {pred }}$ & $\mathrm{R}_{\text {pred }} / \mathrm{R}_{\exp }$ \\
\hline Ricci et al. [29] & 0.114 & 0.231 \\
\hline Angel [23] & 0.186 & 0.376 \\
\hline NZSEE 2017 [38] & 0.932 & 1.885 \\
\hline FEMA 274 [39] & 0.760 & 1.538 \\
\hline FEMA 356 [40] & 0.760 & 1.538 \\
\hline ASCE/SEI 41-06 [41] & 0.760 & 1.538 \\
\hline ASCE/SEI 41-13 [42] & 0.760 & 1.538 \\
\hline ASCE/SEI 41-17 [44] & 0.600 & 1.213 \\
\hline FEMA 306 [43] & 0.927 & 1.875 \\
\hline Morandi et al. [45] & 0 & 0.492 \\
\hline Cavaleri et al. [47] & 0.243 & 1.449 \\
\hline Di Domenico et al. (thin walls) [36] & 0.716 & 1.560 \\
\hline Di Domenico et al. (thick walls) [36] & 0.771 & 0.963 \\
\hline da Porto et al. [35] & 0.476 & 0.809 \\
\hline Verlato et al. [46] & 0.400 & 0.809 \\
\hline Akhoundi et al. [31] & 0.400 & 1.092 \\
\hline Ricci et al. (thin walls) [30] & 0.540 & 1.359 \\
\hline Ricci et al. (thick walls) [30] & 0.672 & \\
\hline
\end{tabular}

As it can be seen from the Figure 16 and Table 2, the closest prediction of the reduction factor for the test specimen T2 was obtained using Equation 10, proposed by da Porto et al. [35]. Reduction factor calculated using above mentioned Equation 10 is 0.476 , while reduction factor calculated from the experimental campaign was 0.494 . The reason for this good match is probably in the fact that Equation 9 is fitted for the walls which had same thickness as wall T2, and similar $\mathrm{h} / \mathrm{t}$ ratio. Also, reduction coefficient proposed by Ricci et al. [30] showed good match with the experimental one, as it slightly overestimates walls out-of-plane capacity. This reduction coefficient is calculated using Equation 7. Among all other Equations, only the Equation 12 is fitted for the walls with smaller slenderness ratios than 15, but this Equation 12 also doesn't give satisfying match, as it is calibrated only on one experimental campaign from the literature, using statistical regression. Regarding the level of in-plane drift, presented Equations are valid for drift values until $1.2 \%$, which was the drift level imposed in the experimental campaign. However, it is important to mention that reduction factor of 0.494 for wall specimen T2 should be taken with reserve, having in mind that connection of masonry infill to the concrete frame is not constructed in usual manner. Regarding that, this high quality connection could potentially increase residual out-of-plane capacity and overestimate reduction factor, compared with the situation when connection joints are constructed as in practice. Nevertheless, it can be concluded that, even though there is certain amount of existing equations which take into account reduction of out-of-plane capacity due to prior in-plane loading, they are empirical - based and fitted only for some results available from the literature, or only for one existing experimental campaign. Regarding that, conclusion is that they can be used for calculation of the reduction factor if wall parameters are very similar to the ones for which these equations are calibrated, but there is a need for developing new equations which can take into account reduction of out-of-plane capacity due to in-plane damage for more general application. 


\section{CONCLUSIONS}

In this paper, influence of prior in-plane damage on the out-of-plane capacity of masonry infills has been investigated. First, literature review of previous experimental campaigns dealing with this topic has been conducted. It has been pointed out that all the studies concluded that prior in-plane damage of masonry infill walls decreases stiffness of the wall and initiates higher displacements in out-of-plane direction.

Since experimental test on full scale specimens, investigating influence of in-plane loading on out-of-plane capacity, are rare, experimental campaign on two different wall specimens made of clay brick masonry, was conducted. Wall specimen denoted as T1 was subjected to cyclic out-of-plane loading until failure. Failure occurred at the load of $176 \mathrm{kN}$. Wall denoted as T2 was loaded in two phases. In the first phase, in-plane load was imposed on the system in 15 cycles, each containing 3 amplitudes. Highest drift level that was reached was $1.2 \%$, and the wall peak force occurred at drift level of $0.8 \%$. Afterwards, specimen was unloaded in in-plane direction, and out-of-plane cyclic load was imposed in 11 cycles. At the load of $87 \mathrm{kN}$, high increase of out-of-plane displacement followed by the decrease of the force occurred, and the test was stopped.

Analyzing the results from conducted experimental campaign it can been concluded that in-plane drift significantly decreases out-of-plane strength capacity and stiffness of masonry infills. Also, it changes the behaviour of the wall in a way that walls exhibit more ductile behaviour due to the higher deformability of mortar joints, if previously, in-plane force is introduced. Out-of-plane displacements at failure in test T1 were low due to different type of the behaviour of the wall than expected. The reason for that were boundary conditions at the connection of masonry infill to the surrounding concrete. Reason for that lies in the fact that, for the placing of mortar, high-pressure pump was used. This pump is not used so far in practice, so it can be said that above mentioned conclusions represent the situation with perfect boundary conditions and very high mortar bond strength, which is not the case in the practice. Due to this construction procedure and mortar bond strength, crack planes for the out-of-plane rotation of infill walls were moved from the top and bottom connection of masonry infills to the first and last row of the bricks. This led to fast and brittle failure of the specimen T1, when the tensile cracks penetrated through the thickness of the wall, destroying thin webs of the brick.

Wall denoted as T2 had reduction of out-of-plane capacity of $51 \%$ compared to the wall specimen denoted as T1, as a consequence of prior in-plane damage. In-plane drift of $1.2 \%$ damaged the wall, which had some minor and some moderate damages. Most common damage of the bricks was falling out of the outer shells of the bricks in the middle two rows of the wall. From the investigation at the site, it can be pointed out that these bricks probably had to be replaced, if the same situation happened in the building. This implies that repair would not be an option. Also, due to high compressive forces, some bricks near the columns exhibit diagonal cracks, which were also visible in the concrete columns. Mortar joints at the connection of masonry infill and concrete were cracked. This cracks in mortar joints didn't jeopardize two-way arching of the masonry infill wall, which stayed in contact with surrounding concrete until the end of the test. Also, it is important to point out that even though in-plane damage decreased out-of-plane capacity of the wall, the wall still had significant amount of out-of-plane capacity.

It can be concluded that prior in-plane damage has to be taken into account when out-ofplane capacity of the wall is discussed, and that this interaction poses an important factor and safety hazard for masonry infill walls during seismic events. 
Results from test campaign for the out-of-plane capacity with prior in-plane damage were compared with analytical approaches for reduction of out-of-plane capacity from the literature. Best match was noticed with the approach proposed by da Porto et al. [35], due to similar wall parameters. Nevertheless, it has been concluded that reduction factor equations from the literature are empirical - based and that results from those equations need to be taken with reserve. Further investigations are needed and they are planned as the part of comprehensive experimental campaign within the AIF project "Development of innovative approach for decoupling infills and non-load bearing masonry walls from the main structure" [37].

\section{ACKNOWLEDGEMENTS}

The authors would like to acknowledge the support from the "Institut für Ziegelforschung Essen e.V" and express their special thanks to Dr. Matija Gams from the University of Ljubljana for the support and fruitful discussions during the execution of experimental campaign within "Development of innovative approach for decoupling infills and non-load bearing masonry walls from the main structure" project.

\section{REFERENCES}

[1] R. Villaverde, Seismic design of secondary structures : State of the art, J. Struct. Eng. (1997) 1011-1019.

[2] N.I. of S. and Technology, Seismic Analysis, Design, and Installation of Nonstructural Components and Systems - Background and Recommendations for Future Work, 2017.

[3] H. Sucuoğlu, Implications of masonry infill and partition damage in performance perception in residential buildings after a moderate earthquake, Earthq. Spectra. 29 (2013) 661-667.

[4] F. Braga, V. Mandredi, A. Masi, A. Salvatori, M. Vona, Performance of non-structural elements in RC buildings during the L' Aquila, 2009 earthquake, Bull. Earthq. Eng. (2010) 307-324.

[5] V. Manfredi, A. Masi, Combining in-plane and out-of-plane behaviour of masonry infills in the seismic analysis of RC buildings, Earthq. Struct. 6 (2014) 515-537.

[6] B. Zhao, F. Taucer, T. Rossetto, Field investigation on the performance of building structures during the 12 May 2008 Wenchuan earthquake in China, Eng. Struct. 31 (2009) 1707-1723.

[7] FEMA74, FEMA E-74 6: Seismic Protection of Nonstructural Components, (2011) 106-117.

[8] N. Fardis, Seismic design,assessment and retrofitting of concrete buildings based on EN-Eurocode 8, 2009.

[9] R.S. Vicente, H. Rodrigues, H. Varum, A. Costa, J.A.R.M. da Silva, Performance of masonry enclosure walls: Lessons learned from recent earthquakes, Earthq. Eng. Eng. 
Vib. 11 (2012) 23-34.

[10] S. Taghavi, E. Miranda, Response assessment of nonstructural building elements, 2003.

[11] P.G. Asteris, S.T. Antoniou, D.S. Sophianopoulos, C.Z. Chrysostomou, Mathematical macromodeling of infilled frames: State of the art, J. Struct. Eng. 137 (2011) 15081517.

[12] C.Z. Chrysostomou, P.G. Asteris, On the in-plane properties and capacities of infilled frames, Eng. Struct. 41 (2012) 385-402.

[13] L. Liberatore, F. Mollaioli, Influence of masonry infill modelling on the seismic response of reinforced concrete frames, Civil-Comp Proc. (2015).

[14] T. Nicola, C. Leandro, C. Guido, S. Enrico, Masonry infilled frame structures: State-ofthe-art review of numerical modelling, Earthq. Struct. 8 (2015) 225-251.

[15] A. Menon, G. Magenes, Definition of seismic input for out-of-plane response of masonry walls: I. parametric study, J. Earthq. Eng. 15 (2011) 165-194.

[16] M.J.. Priestley, Seismic behaviour of unreinforced masonry walls, Bull. New Zeal. Natl. Soc. Earthq. Eng. 18 (1985).

[17] T. Paulay, M.J.. Priestley, Seismic Design of Reinforced Concrete and Masonry Building, 1992.

[18] M.C. Griffith, G. Magenes, G. Melis, L. Picchi, Evaluation of out-of-plane stability of unreinforced masonry walls subjected to seismic excitation, J. Earthq. Eng. 7 (2003) $141-169$.

[19] M. Di Domenico, Out-of-plane seismic response and modelling of unreinforced masonry infill walls, University of Naples Federico II, 2018.

[20] D. Abrams, O. Alshawa, P.B. Lourenco, L. Sorrentino, Out-of-Plane Seismic Response of Unreinforced Masonry Walls : Conceptual Discussion, Research Needs, and Modeling Issues, Int. J. Archit. Herit. (2017).

[21] J.L. Dawe, C.K. Seah, Out-of-plane resistance of concrete masonry infilled panels, Can. J. Civ. Eng. 16 (1989) 854-864.

[22] P. Ricci, M. Di Domenico, G.M. Verderame, Effects of the In-Plane/Out-of-Plane Interaction in URM Infills on the Seismic Performance of RC Buildings Designed to Eurocodes, J. Earthq. Eng. (2020).

[23] R. Angel, D. Abrams, Behaviour of Reinforced Concrete Frames with Masonry Infills, 1994.

[24] R.D. Flanagan, R. Bennett, Biderctional Behaviour of Structural Clay Tile Infilled Frames, J. Struct. Eng. 125 (1999) 236-244.

[25] G.M. Calvi, D. Bolognini, Seismic response of reinforced concrete frames infilled with weakly reinforced masonry panels, J. Earthq. Eng. 5 (2001) 153-185.

[26] F. da Porto, G. Guidi, M. Dalla Benetta, N. Verlato, Combined In-Plane/Out-of-Plane Experimental Behaviour of Reinforced and Strengthened Infill Masonry Walls, 12th Can. Mason. Symp. (2013) 1-11.

[27] P. Morandi, S. Hak, G. Magenes, Out-of-plane experimental response of strong masonry infills, 9th Int. Mason. Conf. July 7, 8, 9; 2014; Guimarães. (2014) 1-12. 
[28] A. Furtado, A. Arêde, H. Varum, H. Rodrigues, Experimental study of the out-of-plane behaviour of masonry infill walls with and without previous in-plane damage, Brick Block Mason. Trends, Innov. Challenges - Proc. 16th Int. Brick Block Mason. Conf. IBMAC 2016. (2016) 1201-1208.

[29] P. Ricci, M. Di Domenico, G.M. Verderame, Experimental assessment of the inplane/out-of-plane interaction in unreinforced masonry infill walls, Eng. Struct. 173 (2018) 960-978.

[30] P. Ricci, M. Di Domenico, G.M. Verderame, Experimental investigation of the influence of slenderness ratio and of the in-plane/out-of-plane interaction on the out-ofplane strength of URM infill walls, Constr. Build. Mater. 191 (2018) 507-522.

[31] F. Akhoundi, G. Vasconcelos, P. Lourenço, Experimental Out-Of-Plane Behavior of Brick Masonry Infilled Frames, Int. J. Archit. Herit. 14 (2018) 221-237.

[32] C. Butenweg, M. Marinković, R. Salatić, Experimental results of reinforced concrete frames with masonry infills under combined quasi - static in - plane and out - of - plane seismic loading, Bull. Earthq. Eng. 17 (2019) 3397-3422.

[33] M.T. De Risi, M. Di Domenico, P. Ricci, G.M. Verderame, G. Manfredi, Experimental investigation on the influence of the aspect ratio on the in-plane/out-of-plane interaction for masonry infills in RC frames, Eng. Struct. 189 (2019) 523-540.

[34] X. Xie, Z. Qu, H. Fu, L. Zhang, Effect of prior in-plane damage on the out-of-plane behavior of masonry infill walls, Eng. Struct. 226 (2021) 111380.

[35] F. da Porto, M. Donà, N. Verlato, G. Guidi, Experimental Testing and Numerical Modeling of Robust Unreinforced and Reinforced Clay Masonry Infill Walls, With and Without Openings, Front. Built Environ. 6 (2020).

[36] M. Di Domenico, M.T. De Risi, P. Ricci, G.M. Verderame, G. Manfredi, Empirical prediction of the in-plane/out-of-plane interaction effects in clay brick unreinforced masonry infill walls, Eng. Struct. 227 (2021)

[37] Development of an innovative approach for decoupling masonry infills and non loadbearing masonry walls from the main structure, https://www.cwe.rwth-aachen.de/earthquake-engineering-projects/development-of-an-innovative-approach-for-decouplinginfills-and-non-load-bearing-masonry-walls-from-the-main-structure/

[38] New Zealand Society for Earthquake Engineering (NZSEE), The Seismic Assessment of Existing Buildings (the Guidlines),Part C - Detailed Seismic Assessment ,2017.

[39] FEMA 274. NEHPR Commentary on the Guidlines for the Seismic Rehabilitation of Buildings, published by the Federal Emergency Management Agency, Washington, DC, 1997.

[40] FEMA 356. Prestandard and comentary for the seismic rehabilitation of buildings. Washington, DC. 2000.

[41] ASCE/SEI 41-06. Seismic rehabilitation of existing buildings. American Society of Civil Engineers, 2006.

[42] ASCE/SEI 41-13. Seismic rehabilitation of existing buildings. American Society of Civil Engineers, 2013.

[43] FEMA 306. Evaluation of earthquake damaged concrete and masonry wall buildings, 
basic procedures manual, published by the Federal Emergency Management Agency, Washington, DC., (n.d.).

[44] ASCE/SEI 41-17. Seismic rehabilitation of existing buildings. American Society of Civil Engineers, 2017..

[45] P. Morandi, S. Hak, G. Magenes, Simplified Out-of-plane Resistance Verification for Slender Clay Masonry Infills in RC Frames, (2013).

[46] N. Verlato, G. Guidi, F. da Porto, Experimental testing and numerical modelling of infill masonry walls subjected to in-plane damage, Proc. Second Eur. Conf. Earth Eng. Seismol. 25-29 August 2014, Istanbul, Turkey.

[47] L. Cavaleri, M. Zizzo, P.G. Asteris, Residual out-of-plane capacity of infills damaged by in-plane cyclic loads, Eng. Struct. 209 (2020) 109957. 